\title{
Analisis Pengaruh Biaya Operasional terhadap Pendapatan dan Dampaknya Terhadap Laba Bersih pada CV. Arif Jaya Motor Medan
}

\begin{abstract}
Author: Ayu Setia Ningsih ${ }^{1}$ Yus Epi ${ }^{2}$

Afiliation:

Politeknik Ganesha Medan

Corresponding email yus_epi@yahoo.co.id

Histori Naskah: Submit: 07-06-2021 Accepted: 07-06-2021 Published: 08-07-2021

Abstrak: Penelitian ini didasari oleh sebuah presepsi yang menyatakan bahwa biaya operasional dapat mempengaruhi pendapatan dan berdampak terhadap laba bersih. Tingginya biaya operasional dalam suatu perusahaan tentu menjadi beban tersediri bagi perusahaan mengingat pendapatan yang diperoleh dari hasil penjualan belum tentu sepadan dengan yang dikorbankan. Tujuan penelitian ini adalah untuk mengalisis apakah biaya operasional mempengaruhi pendapatan dan berdampak terhadap laba bersih pada CV.Arif Jaya Motor Medan periode caturwulan 2018. Metode penelitian yang telah dilakukan yaitu metode Statistik Deskriptif dengan cara mengumpulkan informasi data berupa laporan data barang dagang dan laporan laba rugi. Kemudian dilakukan analisa dengan melihat data disetiap catur wulannya kemudian dilakukan penganalisaaan data apakah mengalami peningkatan atau penurunan. Hasil setelah dianalisis menunjukkan bahwa tingginya beban operasional diimbangi dengan tingginya pendapatan sehingga tidak mempengaruhi kondisi laba bersih perusahaan. Hal ini menunjukkan bahwa beban operasional tidak mempengaruhi kondisi laba bersih jika nilai pendapatan perusahaan mengalami peningkatan. Laba bersih mengalami pengingkatan karena didasari oleh tingginya nilai pendapatan. Untuk catur wulan I, perusahaan memiliki beban operasional sebesar Rp 26.050.000, dari beban operasional tersebut, memperoleh laba bersih sebesar Rp 15.950.000 dengan nilai presentase sebesar 6,4\% dari nilai penjualan bersih Rp 251.600.000. Untuk catur wulan II, perusahaan memiliki beban operasional sebesar Rp 28.500.000 dimana laba yang diperoleh untuk periode ini sebesar $\mathrm{Rp}$ 54.200 .000 dengan hasil presentasi $22 \%$ dari nilai penjualan bersih yaitu Rp 249.200.000. Presentasi di periode III kian meningkat mengingat pendapatan yang diperoleh tinggi yaitu sebesar Rp 307.000.000 sehingga pada periode III , laba bersih memperoleh $32 \%$ dengan biaya operasional sebesar Rp 31.930.000.
\end{abstract}

Kata kunci: Biaya Operasional, Pendapatan , Laba Bersih

\section{Pendahuluan}

Persaingan antara perusahaan dewasa ini semakin berkembang pesat. Untuk itu perusahaan harus menciptakan berbagai inovasi agar dapat bersaing di dunia industri. Kemampuan perusahaan dalam melahirkan suatu produk harus sejalan dengan kebutuhan pasar. Perusahaan dagang merupakan perusahaan yang bisnis utamanya membeli barang dari pemasok dan menjual lagi ke konsumen tanpa mengubah wujud barang tersebut. Dalam mewujudkan produk yang bernilai baik, perusahaan sudah pasti akan mengeluarkan banyak biaya dengan beragam kebutuhan yang juga semakin kompleks. Untuk itu perusahaan harus menciptakan keunggulan sendiri atas produk yang dijual agar dapat menarik nilai jual kepada masyarakat. 
Namun dalam melahirkan keunggulan, perusahaan harus mengorbankan nilai agar sumber daya dan sumber ekonomis dapat menghasilkan suatu produk yang memiliki nilai jual tinggi sehingga dapat meningkatkan laba. Laba atau rugi suatu perusahan dagang dihitung dengan cara mengurangkan biaya untuk memperoleh pendapatan dari hasil penjualan pada periode yang bersangkutan. Biaya merupakan pengorbanan yang harus dikeluarkan demi memperoleh pendapatan. Suatu perusahaan harus memperoleh pendapatan yang tinggi dibandingkan dengan biaya yang dikeluarkan agar memperoleh laba tinggi.

Irene Sukma Lestari Barus, Mochamad Kohar Mudzakar, dan Acep Edison, (Analisis Pengaruh Beban Operasional Pada pendapatan Usaha Dampaknya Terhadap Laba Bersih Pada Perusahaan Food and Beverage, 2010-2014), menyimpulkan bahwa beban operasional mempunyai hubungan yang signifikan terhadap laba bersih pada perusahaan Food dan Beverage yang terdaftar di Bursa Efek Indonesia periode 2010-2014.

CV. Arif Jaya Motor Medan merupakan perusahaan yang bergerak dalam bidang usaha dagang yang dimulai pada tahun 2018. Perusahaan ini dalam mencatat laporan keuangannya tidak sesuai dengan standar pelaporan keuangan sehingga arus masuk pendapatan dan pengeluaran tidak tercatat secara baik. Karena sistem pencatatan dan pelaporan keuangan yang belum sesuai standar, mengakibatkan penerimaan dan pengeluaran kas tidak dapat disajikan secara terperinci sehingga laba dalam perusahaan tidak dapat diperhitungkan.

Berdasarkan dari latar belakang diatas, maka dapat dirumuskan masalah yaitu bagaimana analisis pengaruh biaya operasional terhadap pendapatan dan dampaknya terhadap laba bersih pada CV.Arif Jaya Motor Medan?. Batasan masalah dalam penelitian ini adalah Biaya Operasional terhadap Pendapatan Terhadap Laba bersih pada CV. Arif Jaya Motor Medan.

\section{Studi Literatur \\ Pengertian Biaya}

"Biaya mempunyai dua pengertian yaitu pengertian secara luas dan secara sempit. Biaya dalam arti luas adalah pengorbanan sumber ekonomi yang diukur dalam satuan uang dalam usahanya untuk mendapatkan sesuatu untuk mencapai tujuan tertentu baik yang sudah terjadi dan belum terjadi/baru direncanakan. Biaya dalam arti sempit adalah pengorbanan sumber ekonomi dalam satuan uang untuk memperoleh aktiva." (Sujarweni, 2015) .

Pengertian biaya menurut Mulyadi (2015:8) "Biaya adalah pengorbanan sumber ekonomis yang diukur dalam satuan uang, yang telah terjadi, sedang terjadi atau yang kemungkinan akan terjadi untuk tujuan tertentu."

Menurut Kautsar Riza Salman (2016) menjelaskan bahwa: "Biaya didefinisikan sebagai nilai tukar, pengeluaran, pengorbanan yang dilakukan ntuk menjamin perolehan manfaat".

Dari pengertian diatas, dapat disimpulkan bahwa pengertian Biaya adalah pengorbanan dalam memperoleh suatu tujuan baik yang sudah terjadi, akan terjadi maupun belum terjadi yang berdasarkan atas sumber ekonomi yang diukur dalam satuan uang dalam memperoleh aktiva. Biaya yang ada dalam kegiatan 
operasional bertujuan untuk memperoleh manfaat atas hasil yang dikorbankan dengan tujuan untuk memperoleh laba.

\section{Pengertian Pendapatan}

Ikatan Akuntan Indonesia (2015:23.1) mendefinisikan pendapatan adalah penghasilan yang timbul dari pelaksanaan aktivitas entitas yang normal dan dikenal dengan sebutan yang berbeda, seperti penjualan, penghasilan jasa, bunga, dividen, royalty dan sewa.

Menurut Martani, dkk (2016:204) definisi penghasilan dan pendapatan adalah sebagai berikut: "Penghasilan adalah kenaikan manfaat ekonomi selama suatu periode akuntansi dalam bentuk pemasukan atau penambahan aset atau penurunan liabilitas yang mengakibatkan kenaikan ekuitas yang tidak berasal dari kontribusi penanam modal. Pendapatan adalah penghasilan yang berasal dari aktivitas normal dari suatu entitas dan merujuk kepada istilah yang berbeda-beda seperti penjualan (sales), pendapatan jasa (fees), bunga (interest), dividen (dividend), dan royalti (royalty)."

Dilihat dari berbagai definisi di atas, maka dapat disimpulkan bahwa Pendapatan adalah hasil yang diperoleh atas jasa/produk yang dihasilkan oleh perusahaan meliputi penjualan produk atau jasa kepada pelanggan yang diperoleh dalam suatu aktivitas operasi perusahaan untuk meningkatkan nilai aset serta menurunkan liabilitas yang timbul dalam penyerahan barang atau jasa.

\section{Pengertian Laba Bersih}

Pengertian Laba secara umum adalah kelebihan penghasilan diatas biaya selama satu periode akuntansi. Laba bersih dapat dijadikan sebagai suatu ukuran kinerja perusahaan selama 1 periode tertentu. Laba Bersih dapat disimpan oleh perusahaan dalam akun Laba Ditahan atau dapat didistribusikan kepada pemegang saham dalam bentuk dividen.

Menurut Kasmir (2019:305) menyatakan bahwa pengertian laba bersih (Net Profit) merupakan laba yang telah dikurangi biaya-biaya yang merupakan beban perusahaan dalam suatu periode tertentu termasuk pajak.

Sedangkan menurut kasmir (2019:305) bahwa laba bersih dapat diukur dengan rumus:

$$
\text { Laba Bersih }=\text { Laba Kotor }- \text { Beban Operasi }- \text { Beban Pajak }
$$

Keterangan:

Laba kotor = laba yang berasal dari penjualan dikurangi harga pokok.

Beban operasional $=$ beban dari aktivitas operasi.

Beban pajak = Biaya pajak perusahan pada periode tertentu

Berdasarkan beberapa pendapat tersebut indikator laba bersih dalam penelitian ini adalah laba bersih sama dengan laba kotor dikurangi beban operasi dan beban pajak.

Greuning et al., (2015:39) menyatakan bahwa laba adalah jumlah yang dapat diberikan kepada semua pemegang saham biasa dari induk (yang memiliki kendali maupun tidak). Laba terdiri dari empat elemen utama yaitu pendapatan (revenue), beban (expense), keuntungan (gain), dan kerugian (loss).

Defenisi dari elemen-elemen laba tersebut telah dikemukakan oleh Financial Accounting Standard Board., yaitu :

1. Pendapatan (revenue) adalah arus masuk atau peningkatan lain dari aktiva suatu entitas atau pelunasan kewajibannya (atau kombinasi dari keduanya) dari penyerahan atau produksi suatu barang, pemberian 
jasa, atau aktivitas lain yang merupakan usaha terbesar atau usaha utama yang sedang dilakukan entitas tersebut.

2. Beban (expense) adalah arus keluar atau penggunaan lain dari aktiva atau timbulnya kewajiban (atau kombinasi keduanya) dari penyerahan atau produksi suatu barang, pemberian jasa, atau pelaksanaan aktivitas lain yang merupakan usaha terbesar atau usaha utama yang sedang dilakukan entitas tersebut.

3. Keuntungan (gain) adalah peningkatan dalam ekuitas (aktiva bersih) dari transaksi sampingan atau transaksi yang terjadi sesekali dari suatu entitas dan dari semua transaksi, kejadian, dan kondisi lainnya yang mempengaruhi entitas tersebut, kecuali yang berasal dari pendapatan atau investasi pemilik.

4. Kerugian (loss) adalah penurunan dalam ekuitas (aktiva bersih) dari transaksi sampingan atau transaksi yang terjadi sesekali dari suatu entitas dan dari semua transaksi, kejadian, dan kondisi lainnya yang mempengaruhi entitas tersebut, kecuali yang berasal dari pendapatan atau investasi pemilik.

\section{Pengertian Laporan Laba Rugi}

"Laporan laba rugi (income statement) adalah laporan yang menyajikan ukuran keberhasilan operasi perusahaan selama periode waktu tertentu. Lewat laporan laba rugi, investor dapat mengetahui besarnya tingkat fortabilitas yang dihasilkan investor. Lewat laporan laba rugim klreditor juga dapat mempertimbangkan kelayakan kredit debitor. Penetapan pajak yang nantinya akan disetorkan ke kas negara juga diperoleh berdasarkan jumlah laba bersih yang ditunjukkan lewat laporan laba rugi.” (Hery, 2016)

Ukuran laba menggambarkan kinerja manajemen dalam menghasilkan profil untuk membayar bunga kreditor, dividen investor, dan pajak pemerintah. Akhir-akhir ini, telah banyak dijumpai kecenderungan untuk lebih memperhatikan ukuran laba yang terdapat pada laporan laba rugi dibandingkan dengan ukuran lainnya. Informasi laba juga dapat dipakai untuk mengestimasi kemampuan perusahaan dalam menghasilkan laba dimasayang akan datang (memprediksi atau menafsir earnings power), menafsir risiko dalam berinvestasi, dan lain-lain. (Hery, 2016).

Menurut Kasmir (2016:28), "Laporan laba rugi (income statement) merupakan laporan keuangan yang menggambarkan hasil usaha perusahaan dalam suatu periode tertentu. Di dalam laporan laba rugi ini tergambar jumlah pendapatan dan sumbersumber pendapatan yang diperoleh. Kemudian, juga tergambar jumlah biaya dan jenis biaya yang dikeluarkan selama periode tertentu. Dari jumlah pendapatan dan jumlah biaya ini terdapat selisih yang disebut laba atau rugi."

Dari definisi diatas maka dapat disimpulkan bahwa laporan laba rugi merupakan laporan keuangan yang berisi informasi mengenai pendapatan dan beban selama satu periode akuntansi baik secara operasional perusahaan maupun diluar operasional perusahan. Laporan laba rugi memberi manfaat kepada pihak manajemen sebagai penilaian keberhasilan perusahaan dalam mengelola investasi yang telah ditanamkan oleh pihak investor.

\section{Penelitian Terdahulu}

Berikut hasil penelitian terdahulu yang berkaitan dengan topik penelitian ini yaitu :

\begin{tabular}{|l|l|l|c|l|}
\hline No & Nama Peneliti & Judul Penelitian & Tahun & Hasil Pembahasan \\
\hline 1 & Aria Masdiana & $\begin{array}{l}\text { Pendapatan Usaha Dan } \\
\text { Beban Operasional } \\
\text { Pasaribu }\end{array}$ & 2017 & $\begin{array}{l}\text { 1. Secara Parsial, hasil penelitian } \\
\text { ini menunjukkan bahwa } \\
\text { pendapatan usaha memiliki } \\
\text { pengaruh postif terhadap laba } \\
\end{array}$ \\
& $\begin{array}{l}\text { Perusahaan } \\
\text { Makanan Dan Minuman } \\
\text { bersih. Sedangkan Beban } \\
\text { operasional tidak berpengaruh } \\
\text { terhadap laba bersih. }\end{array}$ \\
\hline
\end{tabular}




\begin{tabular}{|c|c|c|c|c|}
\hline & & & & $\begin{array}{l}\text { 2. Secara simultan, hasil penelitian } \\
\text { ini menunjukkan bahwa variabel } \\
\text { pendapatan usaha dan beban } \\
\text { operasional secara simultan } \\
\text { berpengaruh terhadap laba bersih. }\end{array}$ \\
\hline 2 & $\begin{array}{l}\text { Irene Sukma } \\
\text { Lestari Baros, } \\
\text { Moch.Kohar } \\
\text { Mudzakar dan } \\
\text { Acep Edison }\end{array}$ & $\begin{array}{l}\text { Analisis Pengaruh Beban } \\
\text { Operasional Pada Pendapatan } \\
\text { Usaha Dan Dampaknya } \\
\text { Terhadap Laba Bersih (Studi } \\
\text { Kasus Pada Perusahaan Food } \\
\text { And Beverage Yang } \\
\text { Terdaftar Di Bursa Efek } \\
\text { Indonesia Periode 2010 - } \\
\text { 2014) }\end{array}$ & 2016 & $\begin{array}{l}\text { Hasil statistik } \\
\text { menunjukkan bahwa } \text { deskriptif } \\
\text { variabel baik variabel x } \\
\text { operasional), } \\
\text { variabel y (pendapatan) dan } \\
\text { variabel z (laba) dapat disimpulkan } \\
\text { berdistribusi normal. Hal ini dapat } \\
\text { dilihat melalui probabilitas atas } \\
\text { nilai Jarque Bera dan tingkat } \\
\text { signifikansi 95\% } \\
(\text { Alpha }=5 \%) \text {. }\end{array}$ \\
\hline 3 & $\begin{array}{l}\text { Maulita, M. } \\
\text { Adham, dan } \\
\text { Amiril Azizah. }\end{array}$ & $\begin{array}{l}\text { Analisis Pengaruh Beban } \\
\text { Usaha Dan Pendapatan Usaha } \\
\text { Terhadap Laba Perusahaan } \\
\text { Pada Pt. Arpeni Pratama } \\
\text { Ocean Line Tbk. }\end{array}$ & 2019 & $\begin{array}{l}\text { Pengaruh beban usaha terhadap } \\
\text { laba usaha signifikan dan laba } \\
\text { perusahaan dipengaruhi oleh beban } \\
\text { usaha sebesar } 36 \% \text {. Sedangkan } \\
\text { pengaruh pendapatan usaha } \\
\text { terhadap laba usaha perusahaan } \\
\text { signifikan dan laba perusahaan } \\
\text { dipengaruhi sebesar 12\% dari } \\
\text { pendapatan usaha. }\end{array}$ \\
\hline
\end{tabular}

\section{Metode Penelitian}

\section{Kerangka konseptual}

Kerangka konseptual penelitian ini adalah untuk menganalisi pengaruh tingkat biaya operasional dan pendapatan pada laba perusahaan. Apakah terjadi pengaruh yang signifikan atau tidak. Sugiyono (2015: 128) menyatakan bahwa kerangka konsep akan menghubungkan secara teoritis antara variabel-variabel penelitian yaitu antara variabel independen dengan variabel dependen. Secara ringkas kerangka konseptual yang menjelaskan faktor-faktor yang mempengaruhi kinerja auditor dengan motivasi auditor sebagai variabel moderating.

Berdasarkan uraian diatas, berikut kerangka konseptual yang dibentuk dalam penelitian ini.

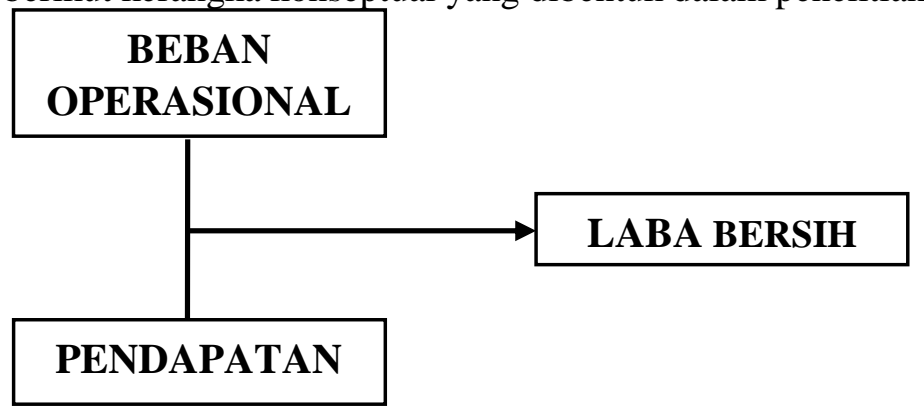

Gambar.3.2 Kerangka Konseptual 


\section{Hasil}

Hasil Penelitian

Deskripsi Data Penelitian

CV.Arif Jaya Motor Medan melakukan penjualan sepeda motor berbagai merk dengan kualitas dan kuantitas yang sesuai pasar. Untuk 2 tahun ini, CV.Arif Jaya Motor Medan menjual 12 merk sepeda motor dengan tahun pembuatan yang berbeda-beda.

Berikut ini data sepeda motor yang diberikan oleh CV.Arif Jaya Motor Medan periode tahun 2018.

Tabel 4.1. Data Pendapatan Perusahaan CV.Arif Jaya Motor Medan Periode Catur Wulan 2018

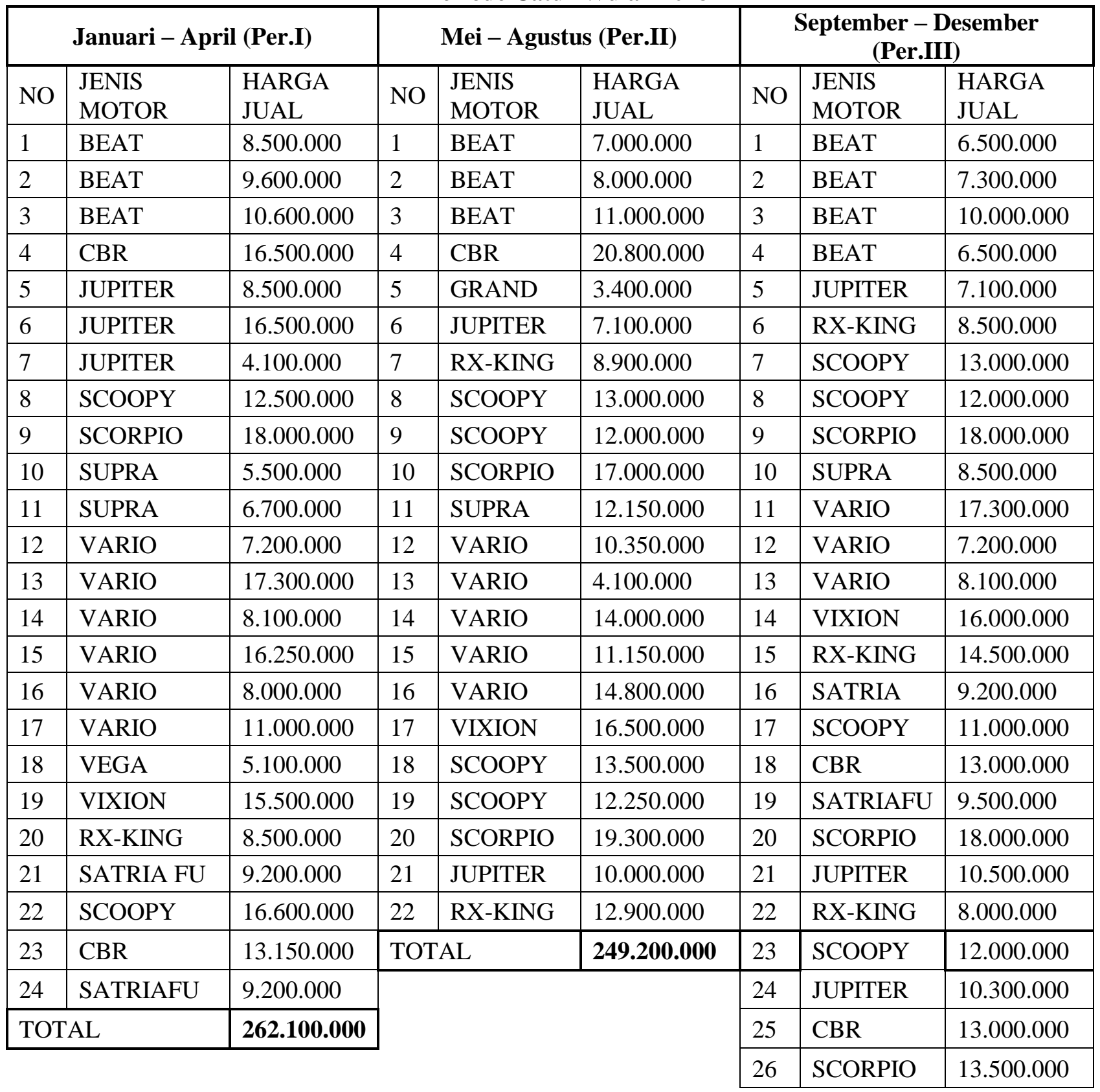


Sumber: Data Skunder, 2018.

\begin{tabular}{|l|l|l|}
\hline 27 & VIXION & 13.500 .000 \\
\hline 28 & RX-KING & 10.500 .000 \\
\hline \multicolumn{2}{|l|}{ TOTAL } & $\mathbf{3 1 2 . 5 0 0 . 0 0 0}$ \\
\hline
\end{tabular}

Dari data diatas, dapat diketahui bahwa CV. Arif Jaya Motor Medan mengalami peningkatan pendapatan setiap periodenya dengan tingkatan kenaikan yang cukup signifikan. Pada periode I, pendapatan mencapai Rp 262.100.000 kemudian meningkat menjadi Rp 259.200.000 di periode II. Untuk periode III, perusahaan kembali memperoleh peningkatan terhadap hasil penjualan sehingga memperoleh pendapatan sebesar Rp 312.500.000. Dari kondisi diatas, menunjukkan kinerja perusahaan yang baik, namun untuk perolehan laba, dapat dilihat setelah adanya beban perusahaan melalui laporan keuangan berupa laporan laba/rugi perusahaan.

Tabel 4.2. Data Biaya Operasional Perusahaan CV.Arif Jaya Motor Medan Periode Catur Wulan 2018

\begin{tabular}{|c|c|c|c|c|c|c|c|}
\hline \multirow{3}{*}{$\begin{array}{r}\text { No } \\
1\end{array}$} & \multirow{3}{*}{$\begin{array}{l}\text { KETERANGAN } \\
\text { HPP (Harga Pokok } \\
\text { Penjualan) } \\
\end{array}$} & \multicolumn{6}{|c|}{ CATUR WULAN 2018} \\
\hline & & \multicolumn{2}{|c|}{$\begin{array}{l}\text { JANUARI - } \\
\text { APRIL (I) }\end{array}$} & \multicolumn{2}{|c|}{ 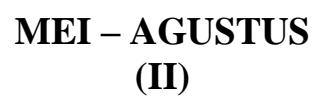 } & \multicolumn{2}{|c|}{$\begin{array}{l}\text { SEPTEMBER - } \\
\text { DESEMBER (III) }\end{array}$} \\
\hline & & & & & & & \\
\hline 2 & Persediaan Awal & $\mathrm{Rp}$ & 50.000 .000 & $\mathrm{Rp}$ & 40.000 .000 & $\mathrm{Rp}$ & 65.000 .000 \\
\hline 3 & Pembelian Barang Dagang & $\mathrm{Rp}$ & 182.600 .000 & $\mathrm{Rp}$ & 175.000 .000 & $\mathrm{Rp}$ & 155.000 .000 \\
\hline 4 & Disc.Pembelian & $\mathrm{Rp}$ & 5.000 .000 & $\mathrm{Rp}$ & 2.500 .000 & $\mathrm{Rp}$ & 4.500 .000 \\
\hline 5 & Retur Pembelian & $\mathrm{Rp}$ & 5.000 .000 & $\mathrm{Rp}$ & 3.000 .000 & $\mathrm{Rp}$ & 2.500 .000 \\
\hline 6 & Biaya Angkut Pembelian & $\mathrm{Rp}$ & 27.000 .000 & $\mathrm{Rp}$ & 22.000 .000 & $\mathrm{Rp}$ & 15.000 .000 \\
\hline 7 & Pembelian Bersih & $\mathrm{Rp}$ & 199.600 .000 & $\mathrm{Rp}$ & 191.500 .000 & $\mathrm{Rp}$ & 163.000 .000 \\
\hline 8 & $\begin{array}{l}\text { Persediaan Tersedia untuk } \\
\text { dijual }\end{array}$ & & 249.600 .000 & $\mathrm{Rp}$ & 231.500 .000 & $\mathrm{Rp}$ & 228.000 .000 \\
\hline 9 & Persediaan Akhir & & 40.000 .000 & $\underline{\mathrm{Rp}}$ & 65.000 .000 & $\underline{\mathrm{Rp}}$ & 50.000 .000 \\
\hline 10 & Harga Pokok Penjualan & $\mathbf{R p}$ & 209.600.000 & $\mathbf{R p}$ & 166.500 .000 & $\mathbf{R p}$ & 178.000.000 \\
\hline 11 & Pengeluaran & & & & & & \\
\hline 12 & Biaya Penjualan: & & & & & & \\
\hline 13 & Beban Iklan & $\mathrm{Rp}$ & 3.500 .000 & $\mathrm{Rp}$ & 4.800 .000 & $\mathrm{Rp}$ & 6.500 .000 \\
\hline 14 & Beban Gaji Karyawan & $\mathrm{Rp}$ & 4.500 .000 & & 4.500 .000 & $\mathrm{Rp}$ & 4.500 .000 \\
\hline 15 & Biaya Service & $\underline{\mathrm{Rp}}$ & 2.500 .000 & $\underline{\mathrm{Rp}}$ & 3.000 .000 & $\underline{\mathrm{Rp}}$ & 4.800 .000 \\
\hline 16 & Total biaya Penjualan & $\mathbf{R p}$ & 10.500 .000 & $\mathbf{R p}$ & 12.300 .000 & $\mathbf{R p}$ & 15.800 .000 \\
\hline 17 & Biaya Administratif: & & & & & & \\
\hline 18 & Biaya Penyusutan & $\mathrm{Rp}$ & 10.000 .000 & $\mathrm{Rp}$ & 10.000 .000 & $\mathrm{Rp}$ & 10.000 .000 \\
\hline 19 & Beban Listrik & $\mathrm{Rp}$ & 350.000 & $\mathrm{Rp}$ & 850.000 & $\mathrm{Rp}$ & 650.000 \\
\hline 20 & Biaya Gaji Staff Kantor & $\mathrm{Rp}$ & 5.000 .000 & & 5.000 .000 & $\mathrm{Rp}$ & 5.000 .000 \\
\hline 21 & Biaya ATK & $\underline{\mathrm{Rp}}$ & 200.000 & $\underline{\mathrm{Rp}}$ & 350.000 & $\underline{\mathrm{Rp}}$ & 480.000 \\
\hline
\end{tabular}


Jurnal Ekonomi Bisnis, Manajemen dan Akuntansi (Jebma)

Volume : 1 | Nomor 1 | Maret 2021 | E-ISSN : 2797-7161 | DOI: 10.47709/jebma.v1n1.971

\begin{tabular}{|c|c|c|c|c|c|c|}
\hline \multirow{3}{*}{$\begin{array}{l}\text { No } \\
22\end{array}$} & \multirow{3}{*}{$\begin{array}{l}\text { KETERANGAN } \\
\text { Total Biaya Administratif }\end{array}$} & \multicolumn{5}{|c|}{ CATUR WULAN 2018} \\
\hline & & $\begin{array}{l}\text { JANUARI - } \\
\text { APRIL (I) }\end{array}$ & \multicolumn{2}{|c|}{$\underset{\text { (II) }}{\text { MEI - AGUSTUS }}$} & \multicolumn{2}{|c|}{$\begin{array}{l}\text { SEPTEMBER - } \\
\text { DESEMBER (III) }\end{array}$} \\
\hline & & 15.550 .000 & $\mathbf{R p}$ & 16.200 .000 & $\mathbf{R p}$ & 16.130 .000 \\
\hline 23 & Total Biaya Operasional & 26.050 .000 & $\mathbf{R p}$ & 28.500 .000 & $\mathbf{R p}$ & 31.930.000 \\
\hline
\end{tabular}

Dari table 4.2 diatas maka dapat lihat bahwa biaya perusahaan setiap periode mengalami fluktuasi pada posisi pengadaan barang dagang yaitu Harga Pokok Penjualan dan mengalami peningkatan pada posisi biaya operasional perusahaan. Untuk posisi harga pokok penjualan, periode I pada akun persediaan awal, memperoleh nilai sebesar Rp 50.000.000 dengan pembelian bersih sebesar Rp 199.600.000, yang dimana pembelian barang dagang sebesar Rp 182.600.000 dengan disc pembelian dan retur pembelian sebesar Rp 10.000.000 dan biaya angkut sebesar Rp 27.000.000. sehingga persediaan barang untuk dijual menjadi Rp 249.600.000, dengan nilai persediaan akhir Rp 40.000.000 maka total harga pokok penjualan periode I sebesar Rp 209.600.000.

Untuk Periode II, nilai harga pokok penjualan sebesar Rp 166.500 .000 , Nilai pembelian bersih di periode II sebesar Rp 175.000.000 dengan disc pembelian dan retur pembelian sebesar Rp 5.500.000 dan biaya angkut sebesar RP 22.000.000,- sehingga total persediaan barang untuk dijual sebesar Rp 231.500 .000 dengan persediaan akhir sebesar Rp 65.000.000.

Untuk periode III, perusahaan melakukan pembelian barang hanya sebesar Rp 155.000.000 dengan memperoleh disc pembelian dan retur pembelian sebesar Rp 7.000.000 dan biaya angkut sebesar Rp 15.000.000 sehingga nilai pembelian bersih sebesar Rp 163.000.000. di periode ini nilai persediaan akhir Rp 50.000.000 sehingga harga pokok penjualan menjadi Rp 178.000.000.

Untuk biaya operasional perusahaan, terjadinya peningkatan biaya disetiap periodenya. Dimana pada periode I total biaya operasional sebesar Rp 26.050.000 dan naik di periode II menjadi Rp 28.500.000 kemudian meningkat lagi di periode III menjadi Rp 31.930.000.

Dari pemaparan diatas perihal biaya operasional perusahaan, maka selanjutnya dilakukan penganalisaan terhadap pengaruh biaya operasional terhadap pendapatan dan dampaknya terhadap laba perusahaan.

\section{Pembahasan}

Analisis Pengaruh Biaya Operasional terhadap Pendapatan dan Dampaknya Terhadap Laba Bersih Dari uraian deskripsi data pendapatan dan biaya operasional perusahaan diatas maka peneliti akan melakukan penganalisaan terhadap data perusahaan. Untuk mengetahui kondisi laba perusahaan, maka diperlukan laporan keuangan perusahaan berupa laporan laba rugi perusahaan periode 2018.

Berikut ini disajikan laporan data keuangan CV.Arif Jaya Motor Medan yang telah dirangkup menjadi periode catur wulan adalah sebagai berikut:

Tabel 4.3. Laporan Laba Rugi CV.Arif Jaya Motor Medan Periode I dan II Catur Wulan 2018 
Jurnal Ekonomi Bisnis, Manajemen dan Akuntansi (Jebma)

Volume : 1 | Nomor 1 | Maret 2021 | E-ISSN : 2797-7161 |DOI: 10.47709/jebma.v1n1.971

\begin{tabular}{|c|c|c|c|c|c|}
\hline \multirow[b]{2}{*}{ No } & \multirow[b]{2}{*}{ KETERANGAN } & \multicolumn{2}{|c|}{ CATUR WULAN 2018} & \multicolumn{2}{|c|}{ FLUKTUASI } \\
\hline & & $\begin{array}{c}\text { JANUARI - } \\
\text { APRIL (I) }\end{array}$ & $\begin{array}{c}\text { MEI - } \\
\text { (II) }\end{array}$ & NAIK & TURUN \\
\hline 1 & Pendapatan Kotor & $\mathrm{Rp} \quad 262.100 .000$ & Rp $\quad 259.200 .000$ & & Rp $\quad 2.900 .000$ \\
\hline 2 & Disc.Penjualan & 3.000 .000 & 1.500 .000 & & $\mathrm{Rp} \quad 1.500 .000$ \\
\hline 3 & Retur Penjualan & 7.500 .000 & 8.500 .000 & 1.000 .000 & \\
\hline 4 & Penjualan Bersih & Rp 251.600.000 & Rp 249.200.000 & & Rp $\quad 2.400 .000$ \\
\hline 5 & \multicolumn{5}{|c|}{ HPP (Harga Pokok Penjualan) } \\
\hline 6 & \multirow{2}{*}{$\begin{array}{l}\text { Persediaan Awal } \\
\text { Pembelian Barang } \\
\text { Dagang }\end{array}$} & $\mathrm{Rp} \quad 50.000 .000$ & 40.000 .000 & \multirow[b]{10}{*}{ Rp 40.700.000 } & $\mathrm{Rp} \quad 10.000 .000$ \\
\hline 7 & & $\mathrm{Rp} \quad 182.600 .000$ & $\mathrm{Rp} \quad 175.000 .000$ & & $\mathrm{Rp} \quad 7.600 .000$ \\
\hline 8 & Disc.Pembelian & 5.000 .000 & 2.500 .000 & & $\mathrm{Rp} \quad 2.500 .000$ \\
\hline 9 & Retur Pembelian & 5.000 .000 & 3.000 .000 & & $\mathrm{Rp} \quad 2.000 .000$ \\
\hline 10 & $\begin{array}{l}\text { Biaya Angkut } \\
\text { Pembelian }\end{array}$ & Rp $\quad 27.000 .000$ & $\mathrm{Rp} \quad 22.000 .000$ & & $\mathrm{Rp} \quad 5.000 .000$ \\
\hline 11 & $\begin{array}{l}\text { Pembelian Bersih } \\
\text { Persediaan }\end{array}$ & Rp $\quad 199.600 .000$ & 191.500 .000 & & $\mathrm{Rp} \quad 8.100 .000$ \\
\hline 12 & $\begin{array}{l}\text { Tersedia untuk } \\
\text { dijual }\end{array}$ & Rp $\quad 249.600 .000$ & Rp $\quad 231.500 .000$ & & Rp $\quad 18.100 .000$ \\
\hline 13 & Persediaan Akhir & Rp $\quad 40.000 .000$ & Rp $\quad 65.000 .000$ & & \multirow{3}{*}{ Rp 43.100.000 } \\
\hline 14 & $\begin{array}{l}\text { Harga Pokok } \\
\text { Penjualan }\end{array}$ & Rp 209.600.000 & Rp 166.500.000 & & \\
\hline 15 & Laba Kotor & Rp $\quad 42.000 .000$ & Rp 82.700 .000 & & \\
\hline 16 & \multicolumn{3}{|l|}{ Pengeluaran } & & \\
\hline 17 & \multirow{5}{*}{$\begin{array}{l}\text { Biaya Penjualan: } \\
\text { Beban Iklan } \\
\text { Beban Gaji } \\
\text { Karyawan } \\
\text { Biaya Service } \\
\text { Total biaya } \\
\text { Penjualan }\end{array}$} & & & & \\
\hline 18 & & 3.500 .000 & 4.800 .000 & 1.300 .000 & \\
\hline 19 & & 4.500 .000 & 4.500 .000 & & \\
\hline 20 & & 2.500 .000 & 3.000 .000 & 500.000 & \\
\hline 21 & & Rp 10.500 .000 & Rp 12.300 .000 & Rp 1.800 .000 & \\
\hline 22 & $\begin{array}{l}\text { Biaya } \\
\text { Administratif: }\end{array}$ & & & & \\
\hline 23 & Biaya Penyusutan & 10.000 .000 & 10.000 .000 & & \\
\hline 24 & Beban Listrik & 350.000 & 850.000 & 500.000 & \\
\hline 25 & $\begin{array}{l}\text { Biaya Gaji Staff } \\
\text { Kantor }\end{array}$ & 5.000 .000 & 5.000 .000 & & \\
\hline 26 & Biaya ATK & 200.000 & 350.000 & 150.000 & \\
\hline 27 & $\begin{array}{l}\text { Total Biaya } \\
\text { Administratif } \\
\end{array}$ & Rp 15.550 .000 & Rp 16.200 .000 & 650.000 & \\
\hline 28 & $\begin{array}{l}\text { Total Biaya } \\
\text { Operasional }\end{array}$ & Rp 26.050 .000 & Rp 28.500 .000 & Rp 2.450 .000 & \\
\hline
\end{tabular}


Jurnal Ekonomi Bisnis, Manajemen dan Akuntansi (Jebma)

Volume : 1 | Nomor 1 | Maret 2021 | E-ISSN : 2797-7161 |DOI: 10.47709/jebma.v1n1.971

\begin{tabular}{|c|l|c|c|c|c|}
\hline \multirow{2}{*}{ No } & \multirow{2}{*}{ KETERANGAN } & \multicolumn{2}{|c|}{ CATUR WULAN 2018 } & \multicolumn{2}{c|}{ FLUKTUASI } \\
\cline { 3 - 6 } & $\begin{array}{c}\text { JANUARI }- \\
\text { APRIL (I) }\end{array}$ & $\begin{array}{c}\text { MEI - AGUSTUS } \\
\text { (II) }\end{array}$ & NAIK & TURUN \\
\hline 29 & Laba Bersih & Rp 15.950 .000 & Rp 54.200 .000 & Rp 38.250.000 & \\
\hline
\end{tabular}

Sumber : CV.Arif Jaya Motor Medan,2018

Pada table 4.3, disajikan laporan yang berisi pendapatan dan beban operasional serta laba perusahaan yang ditampilkan setiap 4 bulan sekali dan disebutkan sebagai periode I dan II. Penjualan bersih mengalami penurunan sebesar $\mathrm{Rp} 2.400 .000$ dimana pada periode I penjualan memperoleh angka sebesar Rp 251.600.000 namun pada periode II hanya memperoleh Rp 249.200.000, kondisi ini disebabkan oleh penjualan sepeda motor yang second lebih tinggi dibandingkan dengan sepeda motor yang baru serta berkurangnya penjualan dikarenakan kondisi ekonomi masyarakat yang minim disertai kebutuhan yang cukup tinggi sehingga daya tarik terhadap sepeda motor berkurang. Untuk Harga Pokok Penjualan, terjadinya penurunan sebesar $\mathrm{Rp} 43.100 .000$ dimana pada periode I, persediaan awal mengalami penurunan sebesar Rp 10.000.000 yang mulanya sebesar Rp 50.000.000 menjadi Rp 40.000.000. Untuk pembelian barang dagang, perusahaan juga mengalami penurunan yang dimana pada periode I, pembelian barang dagang sebesar Rp 182.600.000 namun menurun sebesar Rp 7.600.000 pada periode II menjadi Rp 175.000.000, hal ini terjadi karena adanya penurunan dalam pembelian barang dagang yang dilakukan oleh perusahaan, penurunan ini disebabkan oleh stock barang yang masih cukup untuk penjualan di periode berikutnya sehingga pengadaan barang di periode II ini diminimalkan. Untuk potongan pembelian dan retur pembelian juga mengalami penurunan masing-masing sebesar Rp 2.500.000 dan Rp 2.000.000. Penurunan ini terjadi karena pembelian barang dagang ke pemasok dan masyarakat memperoleh nilai beli yang rendah sehingga potongan pembelian juga rendah dan retur juga tidak tinggi dari kondisi barang yang ada. Biaya angkut pembelian mengalami penurunan sebesar Rp 5.000.000 dikarenakan jarak pemasok dengan perusahaan tidak dalam jarak yang jauh sehingga biaya angkut dapat diminimalkan. Dari kondisi pembelian barang dagang ini maka diperoleh pembelian bersih dengan nilai pada periode I sebesar Rp 199.600.000 dan otomatis menurun di periode II menjadi Rp 191.500.000 karena kondisi diatas.

Untuk laba kotor, terjadi peningkatan sebesar Rp 40.700.000 dimana pada periode I laba kotor sebesar Rp 42.000.000 menjadi Rp 82.700.000 di periode II. Hal ini disebabkan oleh harga pokok penjualan yang rendah sehingga dengan pendapatan yang cukup baik maka dapat memperoleh laba kotor yang tinggi karena harga pokok yang rendah dapat meningkatkan nilai dari laba kotor.

Untuk biaya, baik biaya penjualan maupun biaya administratif, masing - masing mengalami peningkatan disetiap akunnya. Untuk biaya penjualan, beban yang naik adalah biaya iklan dan biaya service, untuk biaya iklan, naik sebesar Rp 1.300.000 yang dimana pada periode I hanya Rp 3.500.000 namun di periode II menjadi Rp 4.800.000, beban iklan dinaikkan guna meningkatkan kegiatan promosi terhadap penjualan sepeda motor. Untuk biaya service, pada periode I hanya sebesar Rp 2.500 .000 namun naik sebesar Rp 500.000 menjadi Rp 3.000.000 pada periode II, kenaikan ini terjadi karena perbaikan terhadap sepeda motor yang dibeli dari masyarakat perlu diadakan service dan pemeliharaan yang cukup banyak agar dapat dijual dengan harga yang tinggi.

Kemudian untuk biaya administratif, mengalami kenaikan sebesar Rp 650.000 yang dimana pada periode I biaya sebesar Rp 15.550.000 dan naik menjadi Rp 16.200.000 di periode II, kenaikan ini disebabkan oleh naiknya biaya listrik dan ATK masing-masing sebesar Rp 500.000 dan Rp 150.000. Kondisi ini disebabkan oleh adanya penambahan ruangan kerja yang digunakan sebagai tempat perbaikan sepeda motor serta 
kurangnya pengawasan terhadap sumber daya manusia dalam penggunaan listrik dan adanya pembelian ATK untuk menunjang pekerjaan dikantor. Dari kondisi ini menyebabkan total biaya operasional naik dimana pada periode I sebesar Rp 26.050.000 naik sebesar Rp 2.450.000 menjadi Rp 28.500.000 pada periode II.

Dari uraian diatas, dapat disimpulkan bahwa kondisi pendapatan yang menurun dengan penurunan yang tidak terlalu rendah dan biaya yang naik dengan kenaikan yang tidak terlalu tinggi, tidak mempengaruhi penilaian terhadap laba bersih. Hal ini dipengaruhi oleh harga pokok penjualan produk yang mengalami penurunan sehingga pendapatan diimbangi dengan harga pokok yang rendah mengakibatkan laba kotor menjadi tinggi. Laba bersih masih memperoleh nilai yang lebih tinggi di periode II yaitu sebesar Rp 92.200.000 dengan selisih naik sebesar Rp 32.250.000 dari periode I yang hanya memperoleh laba bersih Rp 59.950.000. Kondisi ini disebabkan oleh pembelian barang dagang yang dilakukan pada periode II menurun sehingga perusahaan memperoleh laba yang tinggi.

Untuk mengetahui persentase laba yang diperoleh selama periode I dan periode II maka dapat dihitung dalam perhitungan sebagai berikut :

1. Periode I

$\%=\underline{\text { Laba Bersih }} \times 100 \%$

Pendapatan/Penjualan Bersih

$$
=\frac{\operatorname{Rp} 15.950 .000}{\operatorname{Rp} 251.600 .000} \times 100 \%=6,4 \%
$$

2. Periode II

$$
\begin{aligned}
\% & =\underline{\text { Laba Bersih }} \times 100 \% \\
& =\frac{\operatorname{Rp} 54.200 .000}{\operatorname{Rp} 249.200 .000} \times 100 \%=22 \%
\end{aligned}
$$

Dari persentase laba diatas, maka menunjukkan kegiatan operasional perusahaan selama periode I dan II mengalami peningkatan keuntungan yang baik.

\begin{tabular}{|c|c|c|c|c|c|}
\hline \multirow[b]{2}{*}{ No } & \multirow{2}{*}{$\begin{array}{c}\text { KETERANGAN } \\
\text { AKUN }\end{array}$} & \multirow[b]{2}{*}{ MEI - AGUSTUS } & \multirow[b]{2}{*}{$\begin{array}{l}\text { SEPTEMBER - } \\
\text { DESEMBER }\end{array}$} & \multicolumn{2}{|c|}{ FLUKTUASI } \\
\hline & & & & NAIK & TURUN \\
\hline 1 & Pendapatan Kotor & Rp 259.200.000 & Rp 312.500.000 & Rp 53.300.000 & \\
\hline 2 & Disc.Penjualan & 1.500 .000 & 3.500 .000 & $\mathrm{Rp} \quad 2.000 .000$ & \\
\hline 3 & Retur Penjualan & $\begin{array}{l}\mathrm{Rp} \quad 8.500 .000 \\
\end{array}$ & $\begin{array}{ll}\mathrm{Rp} & 2.000 .000 \\
\end{array}$ & & Rp $\quad 6.500 .000$ \\
\hline 4 & Penjualan Bersih & Rp 249.200.000 & Rp 307.000.000 & Rp 57.800.000 & \\
\hline
\end{tabular}

Selanjutnya, untuk mengetahui tingkat keefesienan kegiatan operasional di periode berikutnya, berikut disajikan laporan laba rugi perusahaan dalam bentuk periode II dan periode III adalah sebagai berikut :

Tabel 4.4. Laporan Laba Rugi CV.Arif Jaya Motor Medan Periode II dan III Catur Wulan 2018 
Jurnal Ekonomi Bisnis, Manajemen dan Akuntansi (Jebma)

Volume : 1 | Nomor 1 | Maret 2021 | E-ISSN : 2797-7161 | DOI: 10.47709/jebma.v1n1.971

\begin{tabular}{|c|c|c|c|c|c|}
\hline \multirow[b]{2}{*}{ No } & \multirow{2}{*}{$\begin{array}{c}\text { KETERANGAN } \\
\text { AKUN }\end{array}$} & \multirow[b]{2}{*}{ MEI - AGUSTUS } & \multirow[b]{2}{*}{$\begin{array}{l}\text { SEPTEMBER - } \\
\text { DESEMBER }\end{array}$} & \multicolumn{2}{|c|}{ FLUKTUASI } \\
\hline & & & & NAIK & TURUN \\
\hline 5 & \multicolumn{5}{|l|}{ HPP : } \\
\hline 6 & Persediaan Awal & $\mathrm{Rp} \quad 40.000 .000$ & $\mathrm{Rp} \quad 65.000 .000$ & \multirow{2}{*}{ Rp 25.000.000 } & \multirow{3}{*}{ Rp 20.000.000 } \\
\hline 7 & $\begin{array}{l}\text { Pembelian Barang } \\
\text { Dagang }\end{array}$ & Rp 175.000.000 & Rp 155.000 .000 & & \\
\hline 8 & Disc.Pembelian & $\mathrm{Rp} \quad 2.500 .000$ & $\mathrm{Rp} \quad 4.500 .000$ & \multirow[t]{2}{*}{$\mathrm{Rp} \quad 2.000 .000$} & \\
\hline 9 & Retur Pembelian & $\mathrm{Rp} \quad 3.000 .000$ & $\mathrm{Rp} \quad 2.500 .000$ & & Rp $\quad 500.000$ \\
\hline 10 & $\begin{array}{l}\text { Biaya Angkut } \\
\text { Pembelian }\end{array}$ & $\mathrm{Rp} \quad 22.000 .000$ & $\mathrm{Rp} \quad 15.000 .000$ & \multirow{6}{*}{$\begin{array}{l}\text { Rp } 11.500 .000 \\
\text { Rp 46.300.000 }\end{array}$} & $\mathrm{Rp} \quad 7.000 .000$ \\
\hline 11 & $\begin{array}{l}\text { Pembelian Bersih } \\
\text { Persediaan }\end{array}$ & Rp 191.500.000 & Rp 163.000.000 & & Rp 28.500.000 \\
\hline 12 & $\begin{array}{l}\text { Tersedia untuk } \\
\text { dijual }\end{array}$ & Rp 231.500.000 & Rp 228.000.000 & & Rp 3.500 .000 \\
\hline 13 & Persediaan Akhir & $\begin{array}{ll}\mathrm{Rp} \quad 65.000 .000 \\
\end{array}$ & $\begin{array}{ll}\mathrm{Rp} \quad 50.000 .000 \\
\end{array}$ & & Rp 15.000.000 \\
\hline 14 & $\begin{array}{l}\text { Harga Pokok } \\
\text { Penjualan }\end{array}$ & Rp 166.500.000 & Rp 178.000.000 & & \\
\hline 15 & Laba Kotor & Rp 82.700 .000 & Rp 129.000.000 & & \\
\hline 16 & \multicolumn{3}{|l|}{ Pengeluaran } & & \\
\hline 17 & Biaya Penjualan: & & & & \\
\hline 18 & Beban Iklan & $\mathrm{Rp} \quad 4.800 .000$ & 6.500 .000 & $\mathrm{Rp} \quad 1.700 .000$ & \\
\hline 19 & $\begin{array}{l}\text { Beban Gaji } \\
\text { Karyawan }\end{array}$ & $\mathrm{Rp} \quad 4.500 .000$ & $\mathrm{Rp} \quad 4.500 .000$ & & \\
\hline 20 & Biaya Service & Rp $\quad 3.000 .000$ & Rp $\quad 4.800 .000$ & $\mathrm{Rp} \quad 1.800 .000$ & \\
\hline 21 & $\begin{array}{l}\text { Total biaya } \\
\text { Penjualan }\end{array}$ & Rp 12.300 .000 & Rp 15.800 .000 & Rp 3.500 .000 & \\
\hline 22 & Biaya Administratif: & & & & \\
\hline 23 & Biaya Penyusutan & $\mathrm{Rp} \quad 10.000 .000$ & $\mathrm{Rp} \quad 10.000 .000$ & & \\
\hline 24 & Beban Listrik & $\mathrm{Rp} \quad 850.000$ & $\mathrm{Rp} \quad 650.000$ & & 200.000 \\
\hline 25 & $\begin{array}{l}\text { Biaya Gaji Staff } \\
\text { Kantor }\end{array}$ & $\mathrm{Rp} \quad 5.000 .000$ & $\mathrm{Rp} \quad 5.000 .000$ & & \\
\hline 26 & Biaya ATK & 350.000 & $\mathrm{Rp} \quad 480.000$ & 130.000 & \\
\hline 27 & $\begin{array}{l}\text { Total Biaya } \\
\text { Administratif }\end{array}$ & Rp 16.200 .000 & Rp 16.130 .000 & & 70.000 \\
\hline 28 & $\begin{array}{l}\text { Total Biaya } \\
\text { Operasional }\end{array}$ & Rp 28.500 .000 & Rp 31.930 .000 & Rp $\quad 3.430 .000$ & \\
\hline 29 & Laba Bersih & Rp 54.200 .000 & Rp 97.070 .000 & Rp 42.870.000 & \\
\hline
\end{tabular}

Pada table 4.4, disajikan laporan yang berisi pendapatan dan beban operasional serta laba perusahaan yang ditampilkan setiap 4 bulan sekali dan disebutkan sebagai periode II dan III. Penjualan bersih mengalami kenaikan yang tinggi sebesar Rp 57.800.000 dimana pada periode II penjualan memperoleh angka sebesar Rp 249.200.000 dan mengalami peningkatan pada periode III dengan memperoleh nilai Rp 307.000.000. 
Jurnal Ekonomi Bisnis, Manajemen dan Akuntansi (Jebma)

Volume : 1 | Nomor 1 | Maret 2021 | E-ISSN : 2797-7161 | DOI: 10.47709/jebma.v1n1.971

Hal ini disebabkan oleh adanya retur penjualan yang menurun dimana pada periode II, retur penjualan Rp 8.500.000 namun menurun menjadi Rp 2.000.000 di periode III, hal ini diikuti oleh potongan penjualan naik sebesar Rp 2.000.000 sehingga menjadi Rp 3.500.000 pada periode III, kenaikan potongan penjualan ini dikarenakan perusahaan memberikan hadiah kepada pelanggan yang membeli sepeda motor tanpa tawaran harga.

Untuk Harga Pokok Penjualan, terjadinya kenaikan sebesar Rp 24.500.000, dimana pada periode II , persediaan awal mengalami kenaikan sebesar Rp 25.000.000 yang mulanya sebesar Rp 45.000.000 menjadi Rp 65.000.000. Hal ini dikarenakan stok barang yang sisa pada periode II memiliki nilai yang tinggi.

Untuk pembelian barang dagang, perusahaan mengalami penurunan yang dimana pada periode II, pembelian barang dagang sebesar Rp 175.000.000 namun menurun sebesar Rp 20.000.000 pada periode III menjadi $\mathrm{Rp} 155.000 .000$, penurunan tersebut terjadi karena adanya pembelian sepeda motor dengan tahun yang rendah. Untuk potongan pembelian mengalami kenaikan sebesar $\mathrm{Rp} 2.000 .000$ dengan retur pembelian mengalami penurunan sebesar Rp 500.000 di periode III. Biaya angkut pembelian mengalami penurunan sebesar Rp 7.000.000, hal ini disebabkan oleh perusahaan membeli sepeda motor kepada pemasok di daerah yang berdekatan dengan perusahaan sehingga biaya angkut rendah. Dari rincian pembelian barang tersebut, mengakibatkan persediaan barang untuk dijual meningkat, dimana pada periode II hanya sebesar Rp 193.500.000 menjadi Rp 203.000.000 di periode III, hal ini dilakukan perusahaan guna untuk menunjang kesiapan perusahaan dalam mempromosikan dagangannya. Dari rincian tersebut, dapat diperoleh harga pokok penjualan dengan kondisi mengalami peningkatan di periode III, dengan adanya kenaikan di harga pokok penjualan namun dikarenakan penjualan mengalami kondisi meningkat, sehingga laba kotor juga memperoleh peningkatan di periode sebelumnya, laba kotor naik sebesar Rp 33.300.000. Dari kondisi ini menunjukkan bahwa penjualan yang tinggi akan memperoleh laba kotor yang tinggi pula walaupun harga pokok penjualan yang diperoleh mengalami kenaikan tetapi masih dapat ditutupi oleh peningkatan penjualan bersih sehingga masih memperoleh nilai laba kotor yang tinggi.

Untuk biaya, biaya penjualan, beban yang naik adalah biaya iklan dan biaya service, untuk biaya iklan, naik sebesar Rp 1.700.000 yang dimana pada periode II hanya Rp 4.800.000 namun di periode III menjadi Rp 6.500.000, hal ini dilakukan karena perusahaan melakukan beberapa kegiatan marketing untuk lebih memperkenalkan perusahaan kepada masyarakat luas. Untuk biaya service, pada periode II hanya sebesar Rp 3.000.000 namun naik sebesar Rp 1.800.000 menjadi Rp 4.800.000 pada periode III, dikarenakan melakukan pemeliharaan sepeda motor menggunakan barang dan alat yang bermutu sehingga nilai biaya service mengalami peningkatan. Kemudian untuk biaya administratif, mengalami penurunan yang minim yaitu sebesar Rp 70.000 yang dimana pada periode II biaya sebesar Rp 16.200.000 dan turun menjadi Rp 16.130.000 di periode III, penurunan ini disebabkan oleh turunnya biaya listrik sebesar Rp 200.000, hal ini dikarenakan sumber daya manusia sudah mulai melakukan efisiensi dalam pemakaian listrik dan untuk biaya Atk meningkat sebesar Rp 130.000 kaena perusahaan perlu mengadakan penambahan atk. Dari kondisi ini menyebabkan total biaya operasional naik dimana pada periode II sebesar Rp 28.500.000 naik sebesar Rp 3.430.000 menjadi Rp 31.930.000 pada periode III.

Dari uraian diatas, dapat disimpulkan bahwa kondisi pendapatan yang tinggi dan biaya yang tinggi, tidak juga mempengaruhi penilaian terhadap laba bersih. Hal ini disebabkan oleh tingginya pendapatan dan kenaikan biaya yang tidak terlalu tinggi dari periode sebelumnya sehingga laba bersih mengalami kenaikan sebesar Rp 42.870.000 di periode III yaitu Rp 97.070.000 dimana pada periode II hanya memperoleh Rp 54.200 .000 .

Dari kondisi diatas, maka dapat dihitung persentase laba yang diperoleh selama periode II dan III dalam perhitungan sebagai berikut :

3. Periode II 


$$
\begin{aligned}
\% & =\underline{\text { Laba Bersih }} \times 100 \% \\
& =\frac{\operatorname{Rp} \quad 92.200 .000}{\operatorname{Rp} 249.200 .000} \times 100 \%=37 \%
\end{aligned}
$$

4. Periode III

$$
\begin{aligned}
\% & =\underline{\text { Laba Bersih }} \times 100 \% \\
& =\frac{\operatorname{Rp} 122.070 .000}{\operatorname{Rp} 307.000 .000} \times 100 \%=40 \%
\end{aligned}
$$

Dari data diatas kita dapat lihat bahwa persentase laba bersih terus mengalami peningkatan. Terjadinya peningkatan laba tersebut disebabkan oleh tingginya nilai pendapatan sehingga biaya operasional dapat tertutupi dengan baik, dan tidak mempengaruhi tingkat perolehan laba bersih. Dari kondisi ini dapat disimpulkan bahwa beban operasional tidak mempengaruhi pendapatan apabila pendapatan yang diperoleh tinggi dan beban yang dikeluarkan tidak tinggi dan laba tidak terpengaruh terhadap biaya operasional yang tinggi karena pendapatan yang tinggi. Perusahaan dalam hal ini sangat baik melaksanakan kegiatan operasionalnya karena mampu mengendalikan pengeluaran operasional sehingga tidak mempengaruhi laba perusahaan.

\section{Kesimpulan}

Berdasarkan dari pembahasan yang telah diuraikan, maka dapat ditarik kesimpulan sebagai berikut :

1. CV.Arif Jaya Motor Medan merupakan perusahaan dagang yang menjual barang dagangan berupa sepeda motor baik secara tunai maupun kredit. Barang dagang diperoleh atau dibeli dari pemasok dan masyarakat yang ingin menjual sepeda motor.

2. Kondisi pendapatan CV.Arif Jaya Motor Medan dalam tahun 2018 dengan melakukan penganalisaan yang dibagi menjadi 3 periode atau caturwulan memperoleh hasil yaitu pendapatan mengalami fluktuasi dimana pada periode I nilai pendapatan sebesar Rp 251.600.000 menjadi Rp 249.200.000 pada periode II. Hal ini disebabkan oleh penjualan sepeda motor yang second lebih tinggi dibandingkan dengan sepeda motor yang baru serta kondisi ekonomi masyarakat yang minim disertai kebutuhan yang cukup tinggi sehingga daya tarik terhadap sepeda motor berkurang. Namun peningkatan kembali terjadi pada periode III dengan memperoleh penjualan bersih sebesar Rp 307.000.000. Hal ini disebabkan oleh meningkatnya daya beli masyarakat dikarenakan perusahaan melakukan promosi yang besar-besaran melalui kunjungan ke rumah-rumah dan memberikan harga yang terjangkau sehingga daya minat masyarakat menjadi tinggi terhadap sepeda motor yang dijual oleh perusahaan.

3. Kondisi biaya CV.Arif Jaya Motor Medan dalam tahun 2018 dengan melakukan penganalisaan yang dibagi menjadi 3 periode atau caturwulan memperoleh hasil yaitu biaya mengalami peningkatan di setiap periodenya. Hal ini disebabkan oleh peningkatan biaya iklan untuk kegiatan promosi dan biaya service untuk pengadaan pemeliharaan terhadap sepeda motor second. Adapun biaya yang naik yaitu biaya listrik pada periode II dikarenakan perusahaan menambah ruangan sebagai tempat untuk perbaikan dan pemeliharaan sepeda motor. Namun, perusahaan mencoba melakukan efisiensi listrik sehingga pada periode III biaya listrik lebih rendah daripada periode II.

4. Laba bersih CV.Arif Jaya Motor Medan mengalami peningkatan yang baik disetiap periodenya. Pada periode I, laba bersih memperoleh nilai sebesar Rp 15.950.000 dengan penjualan bersih sebesar Rp 249.200.000 dan biaya operasional sebesar Rp 28.500.000. Pada periode II, laba bersih mengalami 
peningkatan menjadi Rp 54.200.000 dengan penjualan bersih sebesar Rp 249.200.000 dan biaya operasional $\mathrm{Rp}$ 28.500.000. Pada periode III, laba bersih memperoleh nilai sebesar Rp 42.870.000 dengan pendapatan sebesar $\mathrm{Rp} 307.000 .000$ dan biaya operasional $\mathrm{Rp}$ 31.930.000. Kondisi ini menunjukkan bahwa dengan pendapatan yang tinggi dan biaya operasional yang minim dapat mempengaruhi kondisi laba bersih.

\section{Referensi}

Malayu S.P Hasibuan. 2017. Dasar-dasar Perbankan. Jakarta: Bumi Aksara.

Barus, Irene Sukma, dkk (2016). Analisis Pengaruh Beban Operasional pada Pendapatan Usaha dan Dampaknya Terhadap Laba Bersih (Studi Kasus: Perusahaan Food and Beverage yang Terdaftar di BEI Periode 2010-2014). Conference on Management and Behavioral Studies. e-ISSN NO:2541-2850.

Hery,SE.,M.Si.,CRP.,RSA. 2016. Analisis Laporan Keuangan. Jakarta: Grasindo.

Andi Ratama. 2019. Analisis beban operasional terhadap laba bersih. Medan.

Kasmir. 2019. Analisis Laporan Keuangan. Jakarta: PT. RajaGrafindo Persada

Gita Dwi Lestari. 2019. Pengaruh Pendapatan Terhadap Laba Bersih Bank Syariah Mandiri Indonesia. Bengkulu.

Titin Hartini. 2016. Pengaruh Biaya Operasional Dan Pendapatan Operasional (Bopo) Terhadap Profitabilitas Bank Syariah Di Indonesia. I-Finance Vol. 2. No. 1. Juli 2016.

Aria Masdiana Pasaribu. 2017. Pendapatan Usaha Dan Beban Operasional Terhadap Laba Bersih Pada Perusahaan Makanan Dan Minuman. Jurnal Wira Ekonomi Mikroskil Volume 7, Nomor 02, Oktober 2017

Maulita, M. Adham, dan Amiril Azizah. 2019. Analisis Pengaruh Beban Usaha Dan Pendapatan Usaha Terhadap Laba Perusahaan Pada Pt. Arpeni Pratama Ocean Line Tbk. Samarinda.

Erlinda Puspitaningtyas, Akhmad Toha, Aryo Prakoso. 2017. Pengelolaan Keuangan Laba Rugi pada Home Industry Alat Musik UD Kayu Mas Balung, Jember (Financial Management of Income Steatment at Home Industry on Music Instrument UD Kayu Mas Balung, Jember). ESOSPOL Volume IV Edisi 2, Mei - Agustus 2017; hal. 121 - 126 